\title{
Literature as a Form of Narration: The Issue of Conscience in the Works of Kafka and Dostoevsky
}

\author{
Ayşe Koncavar \\ Assistant to Professor \\ Marmara University, Communication Faculty, Istanbul, Turkey \\ akoncavar@yahoo.com
}

\section{Doi:10.5901/jesr.2013.v3n7p742}

\section{Abstract}

Conscience is a phenomenon that's been emphasized in many religions, philosophical schools of thought and mysticism. According to philosophy, conscience, which warns the person by means of providing a sense of inner peace or discontentment, is not solely a concept but the talent possessed by a person. On the other hand, dialectic argues that conscience is the result of a person's breeding and knowledge determined by the social conditions in which the person lives in. Conscience is an internal voice that distinguishes the right from wrong.In literature, there are certain stories and heroes that are worth being studied meticulously and with attention. For example, Kafka, who describes the fundamental issues brought about by the modern era, has tried to disclose the truth of the century we are living in its rawest and naked form. In his writing, Kafka has always chosen allegorical and metaphorical narratives and through the characters he created, has emphasized the bureaucracy, alienation and the estrangement of human beings from humanistic values. In one of his stories, he tells the story of Gregor Samsa who turns into metamorphoses into a cockroach while in another story, he tells the tragic end of a character who has been sentenced to an undeserved punishment by a bureaucracy that exists outside of himself because of a crime he did not commit.Another example from literary texts will be Dostoyevsky. The love towards those small and poor people as well as the pity felt towards those empty and ridiculous men that live in the society, which is a common theme in the Russian literature, can be witnessed in his novels.At this point, Dostoyevsky as well as Kafka, take a critical look at the system through literature and have provided us with examples of conscience by means of questioning the system through the characters they created.Our subject matter in this text is to reveal that literature, in my opinion the most influential form of which is poetry followed by the novel, is actually an art form in which human beings as well as all concepts pertaining to human beings and to examine the relationship between literature and conscience.

Keywords: literature, conscience, alienation,

"Nothing is more seductive for man than his freedom of conscience, but nothing is a greater cause of suffering." Dostoevsky

"Conscience is our unerring judge until we finally stifle it." Balzac

\section{Literature}

Literature is a field of study which is intimately connected with sub-categories of culture such as art, science and thinking; and must be momentously emphasized due to its complicated attachment with economic, social, political and moral life. For all these properties hereinbefore mentioned, everything that concerns humankind lies within the interests of literature. In its simplest explanation, literature may be defined as logos presenting itself in aesthetics by means of language. Literature may be construed as one of the ways by which humans self-explore and self-realize their eternity within. Literature is a way of approaching beauty as an area where eternity exists by using manners and language. Beauty is not merely a beautiful feeling, but also an area where beautiful eternity manifests itself. ( İnam 2003:21-24)

Another fundamental problem is the function of literature. One opinion discusses that extraordinary development of science and technology, hence the countless pieces due to fragmentation of information led us to live in an era where knowledge is specialized. Specialization will bring many benefits without doubt. However, it also yields negative consequences, because it obliterates common thinking and cultural traces that renders humans' coexistence, mutual communication and standing in solidarity possible. Today, science and technology fail to play an integrative role due to the eternal wealth of knowledge and evolution of knowledge which led to specialization and the perplexities of specialization. Yet literature related occupations serve as one of the common denominators in human life where 
individuals are able to know themselves and talk to each other despite of their purposes, geographical and cultural positions and personal situations in life. Literature has allowed individuals to overcome history within all aspects of their lives. As readers of Cervantes, Shakespeare, Dante, Tolstoy and Dostoevsky we get acquainted with each other while transcending time and space, and sense each other as the members of the same species. Nothing could teacher better than literature to see into the richness of humankind's heritage when facing ethnic and cultural differences, and observe the same as an indication of humans' multi-faceted creativity. Without doubt we enjoy ourselves tremendously while reading good works of literature. In the same breath we learn what we are and how we are in the secret cavities of our consciousness with our image in society and our jobs, dreams and nightmares within our human completeness and our humanly faults, and relationships that tie us to others. ( Llosa $2001: 20$ )

In other words literature educates, trains, excites and pleases. It may impart good and bad feelings, arouse sexual desires. Literature may have and already had an impact on people on these areas.

\section{Conscience}

In terms of the topic at hand, this article will endeavour to dwell upon the conscience as a way of feeling, originating from the etymology of the word conscience before looking into references of conscience in literature.

The word conscience etymologically originates from the Arabic language, and its initial use is known to date back to the thirteenth century. In its simple explanation, it is a character trait where one measures what he/she has done or will do based upon his/her own moral values about his/her intention and behaviours. The concept of the conscience is basically defined as a mental power and instinctual authority or generally a mental capacity that allows individuals and at times drives them to make judgments over a right-wrong and good-bad equilibrium over their own behaviour. Even in the light of this definition, opinions as to the nature and function of conscience differ. As regards to the history of philosophy, we find prominent thinkers who attach great significant to the subject of conscience, as well as thinkers who approach the subject with profound scepticism. Holding a vital place in philosophy history as well as in religious manuscripts, not the term "conscience" (consciencia), but the issue of conscience was conceptually found in the ancient Greek thinking and also found coverage in the thoughts of Roman thinkers and statesmen like Cicero and Marcus Aurelius. Those who emphasized the significance of conscience, beginning with Plato and Aristotle made so by putting conscience at the top of the list of factors that made life worth living. In all these discussions conscience is treated as the leading actor in steering and evaluating our lives that reserves space in human life in parallel to mind. This opinion gains stronger ground in post-Enlightenment European thinking. For instance Montaigne refers to leading a conscience-free life when mentioning "knowing how to be a human" and efforts to live decently: "one who knows how to be a human, successes a much more important thing than those who wrote books or won wars or conquered countries. All acts other than this are like an empty stage to dominate everything, feather one's nest and appropriate possessions. The best work of man is leading a decent and true life". As mentioned earlier, the term conscience is found in Western philosophy in the $13^{\text {th }}$ century for the first time as a Latin origin word with a moral and informative aspect to its definition. According to Nişanyan's etymology dictionary based on Franciscus Meninski's "Thesaurus Linguarum Orientalium", the word penetrates into the Ottoman language only in the $17^{\text {th }}$ century although it implies informative meanings such as understanding, finding and exploring.

We find that in European thinking, the term consciousness is born with its roots in the term conscience and the concepts of consciousness and conscience have gained semantic autonomy and have been used by Descartes along with other philosophers since the $18^{\text {th }}$ century to imply related but different meanings, in parallel with each other. In the modern sense, the term "conscience" also denotes a moral and normative association, while "consciousness" or the term "reason" as so often used similarly in this context refer to a concept concerning knowledge, science and reasoning free from moral association. It is possible to encounter examples recently where conscience and mind concepts are used in deep connection with each other yet with different meanings and used in a way that complement each other when expounding the condition of mankind. For instance, the first article of the Universal Declaration of Human Rights which has been written down after the $2^{\text {nd }}$ World War and published in 1948 with the hope of containing universal observations and principles to appeal to the whole of mankind and contribute to world peace, stipulates, "All persons are born free and equal. They have reason and conscience and should act towards one another in a friendly manner."

The main assumption is that mind and conscience are the two most basic mental capacities that arise from human nature, exist in all individuals and bear functions that are different but complete each other. On the other hand arguments which approach the term conscience with intense scepticism and objecting to the very definition of it seems to grow on from the beginning of the $19^{\text {th }}$ century and came to a climax in the middle of the $20^{\text {th }}$ century. The mood that led Max 
Horkheimer, a Frankfurt School thinker, to write his eclipse of the reason book could also possibly indicate an eclipse of the conscience era for many other philosophers. (Güzeldere 2013:9)

In many religions, philosophical thinking and mysticism, conscience is considered of great significance. In philosophy, the conscience which stimulates the person by imbuing inner peace or inner discomfort is not a concept but an ability of the person. The metaphysic understanding in philosophy sets forth the existence of this gift from birth, whereas dialectic understanding argues that it is the product of etiquette and knowledge stipulated by social conditions of the man. And neo-spiritual approach believes that it is an ability which gradually manifests at only some extent of the spirit in proportion with the development of one's soul (humanity stage after animal stage). Conscience is an inner voice declaring the right and wrong to humans. It is a subjective consciousness that judges, assents to, calls to account, and accuses the person on his/her actions. (Koncavar 2013:195-196)

The main issue of this article is to handle how conscience is dealt with by two men of the literature world, master pens Kafka and Dostoevsky who produced cardinal works on the subject of conscience and their worlds. First, let's look into the world of Kafka.

\section{Kafka}

Describing the fundamental issues of the modern era, in other words modern men or us in his stories and novels, Kafka has concentrated on exposing the most cruel and naked truth of the century we live in. While doing so, he chose an allegoric and metaphoric style narration and the tragic fates of its heroes can still be traced in any one of us, readers' minds with Gregor Samsa in one of his stories transformed into a cockroach due to the red-tape of the system, alienation and deviation from humanely values; and another protagonist in another story who is sentenced to a penalty he did not deserve for a crime he did not committed.

Often lifting the lid on blind alleys of Western society after the $20^{\text {th }}$ century Industry Era, the fake family relations of the bourgeois class and the maddening functioning of bureaucracy, Kafka realized, and with his works dwelled upon, the dead ends of modernity that have emerged with the idea that literary, artistic, social organization in terms of culture and daily life have lost its currency in the traditional sense of the $19^{\text {th }}$ century. (Koncavar 2013:201)

Kafka's world is the world of alienation, of persons divided into two parts. This world is also a world deprived of the awareness of the very same division, a world ready to fall asleep. Kafka's inner world is aware that it belongs to and has sunk into this alienation world, but also full of the desire to wake up those who are asleep.

Kafka's view of the world is limited with his class, and the horizon which ranges based on the constant dilemmas and concerns pertinent to this class. This makes it impossible for Kafka to find the underlying reasons of alienation. Hence Kafka's struggle with alienation could at best be described as "waving one's hand to shake off an image".

Today, alienation does not arise from mankind's weakness in the face of natural forces, but from its desperation in the presence of social powers disguised as an enemy. Any time all hell may break loose and may destroy all, along with all that he created, with his dreams and values. Daily life in the world of alienation is inseparable from this air of concern and doom waiting close by. This is what Kafka renders directly sensible, perceivable; the truth needs no interpretation. Kafka points at the necessity of another world, by reflecting the truth as it is, in other words by setting forth or by merely describing its impeccably functioning mechanism, the intrinsic threats, oppression and compression, the fear one spreads in his/her own heart and head, the sarcasm and rebellion.

Kafka deals with society's judicial mechanisms allegorically in his works. Approaching literature from a historical perspective, it is clear that the two most fundamental works related to judgment and crime, are Kafka's "Trial" and Dostoevsky's "Crime and Punishment". The essential difference between Kafka's protagonists and Dostoevsky's protagonists is that Dostoevsky's Raskolnikov gives an example where crime looks for penalty, whereas Kafka's protagonist Josef K gives an example where penalty looks for crime. (Kundera 1989:123) This comparison reflects Kafka's point of view toward society's organizations and bureaucratic functioning.

In his book Trial, Kafka narrates the story of Josef $\mathrm{K}$ who wakes up to a day when he suddenly gets imprisoned, suspects the whole event is a joke because he fails to learn what he is accused of, then grasps the seriousness of the situation. $\mathrm{K}$ does not bear any defence power whatsoever. As he does not know the accusations against him, he does not know how to defend himself. A gloomy, stressing mood is dominant in the entire book. (Koncavar 2013:216)

Especially with this work Kafka handles the issue of social conscience, because the interrogation of Josef $\mathrm{K}$ who is even deprived of the knowledge of his crime is an issue of social conscience. As a result Kafka wrote The Trial so that the humans in the future may not be judged before unknown judges on the pure account of being humans, and wrote Metamorphoses to demonstrate that the humiliation of a bug is absolutely and without any doubt beneath any human 
being... This is so that people may not dwindle down and act as bugs in their relationships with other people. He penned The Trial so that his fellows can be their own masters, and build such systems that would free mankind of any castles. This is the way of Kafka. He has always construed his writings to be temporary, in other words hoped that one day his stories will not be experienced by other people... This is the sole truth about which once Fisher said that Kafkaism will pass but Kafka will remain.

\section{Dostoevsky}

A thorough look into Dostoevsky's world, his biography may give us an understanding about his fictional characters. The author was born to a Moscovite Catholic family. His father was a medical doctor and her mother was an ill woman. Dostoevsky was an introvert child. He was sent to an engineering school in Petersburg. He learned his father's death by murder while he was a student and never spoke of his father again. He was involved in protests to overthrow the Russian Tsar and bring in the republican rule instead. Finally he got arrested and sentenced to death penalty. Tsar ordered that his conviction be changed to galley slavery. This period of his life had a huge impact on him and left deep traces in his soul. He had to write without break to earn his living.

The main highlight of this article will be to deal with the issue of conscience based on his novel Crime and Punishment and its unforgettable protagonist Raskolnikov.

The protagonist of Dostoevsky's master fiction is a young pupil named Raskolnikov who deeply loves his poor mother and sister. He decides to murder an elderly money-lender woman he knows who is speculated to have some rubles. A series of events strengthen his intentions. For instance, her sister who fails to find a way to pull herself out of poverty is ready to sacrifice her own life for her family and get married to a rich, but old and gruesome man; and Raskolnikov is determined to prevent this marriage. In the meantime he meets a drunkard, an old, small officer with a mellow daughter from his first marriage. This family has descended to the lowest imaginable level after being abandoned to their fate in a way only possible in big cities like St. Petersburg and Raskolnikov establishes a relationship with this family. As the novel progresses, he gradually sinks into a deep distress and notices acute and desperate poverty and trouble leading him to be overwhelmed by the thought of elderly money-lender's murder. He commits the crime but fails to find the money he hoped for; he is not even capable of discovering the money in such a rush. After spending a couple of days agonized with shame and regret and under the pressure of the new conditions that escalates his regret, he goes to the police and confesses that he murdered the old woman and her sister. (Tolstoy 1890, trans.Ozkan 2001: 279 )

Raskolnikov was not himself when he was murdering the old lady or her sister. He was not actually living the real life when murdering the old lady then her sister. To the contrary, he was moving like clockwork; doing something he never had the capacity of doing: He was igniting an explosive he had set off within himself long before that moment. An old woman was murdered, another one was standing beside him and the axe was at his hands. Raskolnikov's real life was not lived in the moment he met the sister of the old woman nor lived before the murder of the latter; so even before he entered that apartment with the murder in his mind, even before he grasped the axe, in fact even before he knitted the knot to hang the axe inside his coat: His life was realized also before contemplating on his sofa if he could polish off an old lady or any other person who seemed a pest or a malice according to someone's arbitrary decision. His real life took place while mulling over issues irrelevant with the old lady like whether he should live in Petersburg, whether he should accept the money sent by his mother. The decision as to whether he could murder the old lady was reached back at that time, in that bestial area of life far from reality. These conclusions were not settled while standing in front of the old lady with an axe in his hand, to the contrary, they were settled in the mere thinking process before he took action, when his consciousness only was active and hardly detectable shifts were conceived in his consciousness. This is why it is of great importance that in order for the emerging problem to be solved correctly the conscience must be clear as possible and it is for the very same reason that just a cigarette or a glass of beer complicates and hinders the solution of a problem; drowns out the voice of conscience and lets one decide according to the man's inferior beastly self and appeal, which is the exact thing what happened with Raskolnikov. ( Tolstoy 1890, trans.Ozkan 2001: 246-247)

The detective who runs the murder investigation judges from the start that Raskolnikov is guilty. However, as he also senses Raskolnikov's conscientious values, his curiosity to learn whether or not he is a menace to society overpowers him. Nevertheless, Raskolnikov is cleansed by confessing to his crime as a Bible Christian although the only evidence proving his guilt disappeared. Eventually regardless of the fact that he killed two women with an axe, committed the premeditated murder of one victim, and voluntary manslaughter of another, he is not sentenced to life time but eight years in prison due to various extenuating circumstances, his moral values, saving a kid in the past while risking his life, and similar cases. 
The "sinner" characters in Dostoevsky's novel are not as "bad" nor constitute a threat to the society and humanity as much as the characters Ivan, Rakitich or Raskolnikov do. Moreover, these characters find salvation in their guilty conscience and suffering in the presence of their sins. In this context, the relationship between sin and atonement has a redemptive function in the angle of conscience for Dostoevsky, whereas the end of those people who consider themselves as super-human free of any moral criteria and think "everything is allowable and tolerable" cannot be redemption or salvation but a definite spiritual destruction.

Sonia in Crime and Punishment is a "clean whore" who reveals the guilty conscience of Raskolnikov and in a way acts as a medium to save his conscience. The steep contrast between Sonia's spiritual immaculateness and social humiliation virtually acts like the symbol of deep abysses and conflicts between a man's spirit and personality.

Nevertheless, the main characteristic of Dostoevsky's novels is the plurality of independent and heterogeneous consciousnesses and voices, an authentic multivocal symphony. What is paraphrased in the novels of Dostoevsky is not the plurality of destinies and characters in one objective world enlightened by a single author consciousness. The plurality of consciousnesses each having equal rights and world of their own rather unite within the wholeness of the plot but never blend in. Dostoevsky's main characters are not merely the object of author's statement by definition of Dostoevsky's creative design, but also the subject of their own indirect interpretational statements. The image of a character created by Dostoevsky is not the familiar objectified image of traditional fiction characters. (Bakhtin 1984:4849)

It is rarely possible to understand which character Dostoevsky sides with. Dostoevsky nearly manages to hold his voice outside or more accurately in the combination of all voices. This aspect does not expose itself as clearly as it does in Tolstoy's novels, as Dostoevsky fragments a personality and unearths it together with all its contradictions. It is therefore of significance that the most "rational" and substantial "doubts" related to God and religion in the entirety of the novel are expressed by Ivan. Ivan is a man of letters with perhaps an impulse toward faith, whose conscience continuously pricks him and, on the other hand, chooses not to believe and theorize his unbelief.

In conclusion, the concept of conscience as handled by the two distinguished authors of literature, Kafka and Dostoevsky, are not treated free of all social attachments.

\section{References}

Bakhtin, Mihail M. (1984). Problems of Dostoevsky's poetics, Minnesota Univ, USA, ( trans. Cem Soydemir, 2004 Dostoyevski Poetikasının Sorunları, Metis Yayınları, İstanbul )

Güzeldere, Güven. (2013). Vicdan: bazen sızlar (Conscience will prick sometimes) Psikeart Magazine, Conscience Issue No. 25, Art Psikiyatri Yayın, İmit

İnam, Ahmet. (2003). Edebiyatını Yitirmiş Edebiyat, Doğu Batı Düşünce Dergisi, yıl 6 sayı 22 , Doğu Batı Yayınları ,ISSN :1303-7242, Ankara

Koncavar, Ayşe. (2013). Edebiyatta vicdan kavramı, Sinema, Iletişim, Edebiyat (Cinema, Communication, Literature), Agora Publishing, İstanbul,

Koncavar, Ayşe. (2013). İletişim Açısından Modernist Bir Yazar Franz Kafka ve İmgelem Dünyası, Sinema, İletişim, Edebiyat (Cinema, Communication, Literature), Agora Publishing, İstanbul,

Kundera, Milan. (1989). Roman Sanatı, transl, İsmail Yergüz. AFA Publishing, İstanbul

Llosa, Mario Vargas. (2001). "Why Literature? " USA: The New Republic, translation "Edebiyat Ne Işe Yarar I-I", by Celal Uster, Radikal Kitap Eki, 08/07/2001, [Online] Available http://blog.metu.edu.tr/korkuyu/yazilar/44-2/ , (20.07.2013)

Tolstoy, Lev. (1890) Dostoevsky, His Life, Articles on His Works and Aphorisms. Article name: How did small changes in conscience made Raskolnikov commit a crime?

Dostoyevski, Hayatı, Eserleri Üzerine Makaleler ve Aforizmalar. Makale adı: Şuurdaki küçücük değişiklikler Raskolnikov'un suç işlemesine nasıl sebep oldu? trans.. M.A.Özkan, Kaknüs yayınları, 2001, İstanbul, 